\title{
Multiple Effects of Changes in Arctic Snow Cover
}

\author{
Terry V. Callaghan, Margareta Johansson, Ross D. Brown, Pavel Ya. Groisman, \\ Niklas Labba, Vladimir Radionov, Raymond S. Bradley, Sylvie Blangy, \\ Olga N. Bulygina, Torben R. Christensen, Jonathan E. Colman, Richard L. H. Essery, \\ Bruce C. Forbes, Mads C. Forchhammer, Vladimir N. Golubev, Richard E. Honrath, \\ Glenn P. Juday, Anna V. Meshcherskaya, Gareth K. Phoenix, John Pomeroy, \\ Arja Rautio, David A. Robinson, Niels M. Schmidt, Mark C. Serreze, \\ Vladimir P. Shevchenko, Alexander I. Shiklomanov, Andrey B. Shmakin, \\ Peter Sköld, Matthew Sturm, Ming-ko Woo, Eric F. Wood
}

\begin{abstract}
Snow cover plays a major role in the climate, hydrological and ecological systems of the Arctic and other regions through its influence on the surface energy balance (e.g. reflectivity), water balance (e.g. water storage and release), thermal regimes (e.g. insulation), vegetation and trace gas fluxes. Feedbacks to the climate system have global consequences. The livelihoods and well-being of Arctic residents and many services for the wider population depend on snow conditions so changes have important consequences. Already, changing snow conditions, particularly reduced summer soil moisture, winter thaw events and rain-on-snow conditions have negatively affected commercial forestry, reindeer herding, some wild animal populations and vegetation. Reductions in snow cover are also adversely impacting indigenous peoples' access to traditional foods with negative impacts on human health and well-being. However, there are likely to be some benefits from a changing Arctic snow regime such as more even run-off from melting snow that favours hydropower operations.
\end{abstract}

Keywords Snow $\cdot$ Arctic $\cdot$ Climate $\cdot$ Albedo · Hydrology · Ecology · Biogeochemical cycling · Geochemical processes · Forestry · Infrastructure · Tourism $\cdot$ Indigenous cultures $\cdot$ Human health

Richard E. Honrath—deceased.

Electronic supplementary material The online version of this article (doi:10.1007/s13280-011-0213-x) contains supplementary material, which is available to authorized users.

\section{INTRODUCTION}

Snow is a dominant feature of the Arctic covering its land, sea, lake and river ice surfaces for 8-10 months each year. Arctic climate has entered a unique period relative to the instrumental record and, in the case of summer temperatures, relative to 2000-year reconstructions of past variations: this trend is expected to continue (Walsh et al. 2011a, b [this issue]). Analysis of in situ and satellite data show evidence of different regional snow cover responses to this warming and increasing winter precipitation over the past 40-50 years. Snow cover over the Arctic is projected to increase in the range of $0-15 \%$ for maximum snow water equivalent (SWE) but decreases in snow cover duration (SCD) by about $10-20 \%$ are projected over much of the Arctic (Callaghan et al. 2011a, b [this issue] and references therein).

Snow cover plays a major role in climate, hydrology and ecological systems through its influence on the surface energy balance (e.g. reflectivity), water balance (e.g. water storage and release), thermal regimes (e.g. insulation), vegetation and trace gas fluxes (Figure 1). The livelihoods and well-being of Arctic residents and many services for the wider population depend on snow conditions so changes in these conditions are likely to have important and far reaching consequences: many impacts, such as feedbacks to the climate system, are likely to have global consequences.

The purpose of this article is to summarize key findings from the SWIPA (Snow, Water, Ice, Permafrost in the Arctic) Assessment (AMAP 2011) related to the impacts of changing snow cover in the Arctic. Part I of the summary focusing on observed snow cover changes, was presented in Callaghan et al. (2011b [this issue]); in this article, we focus specifically on the various impacts of recently 


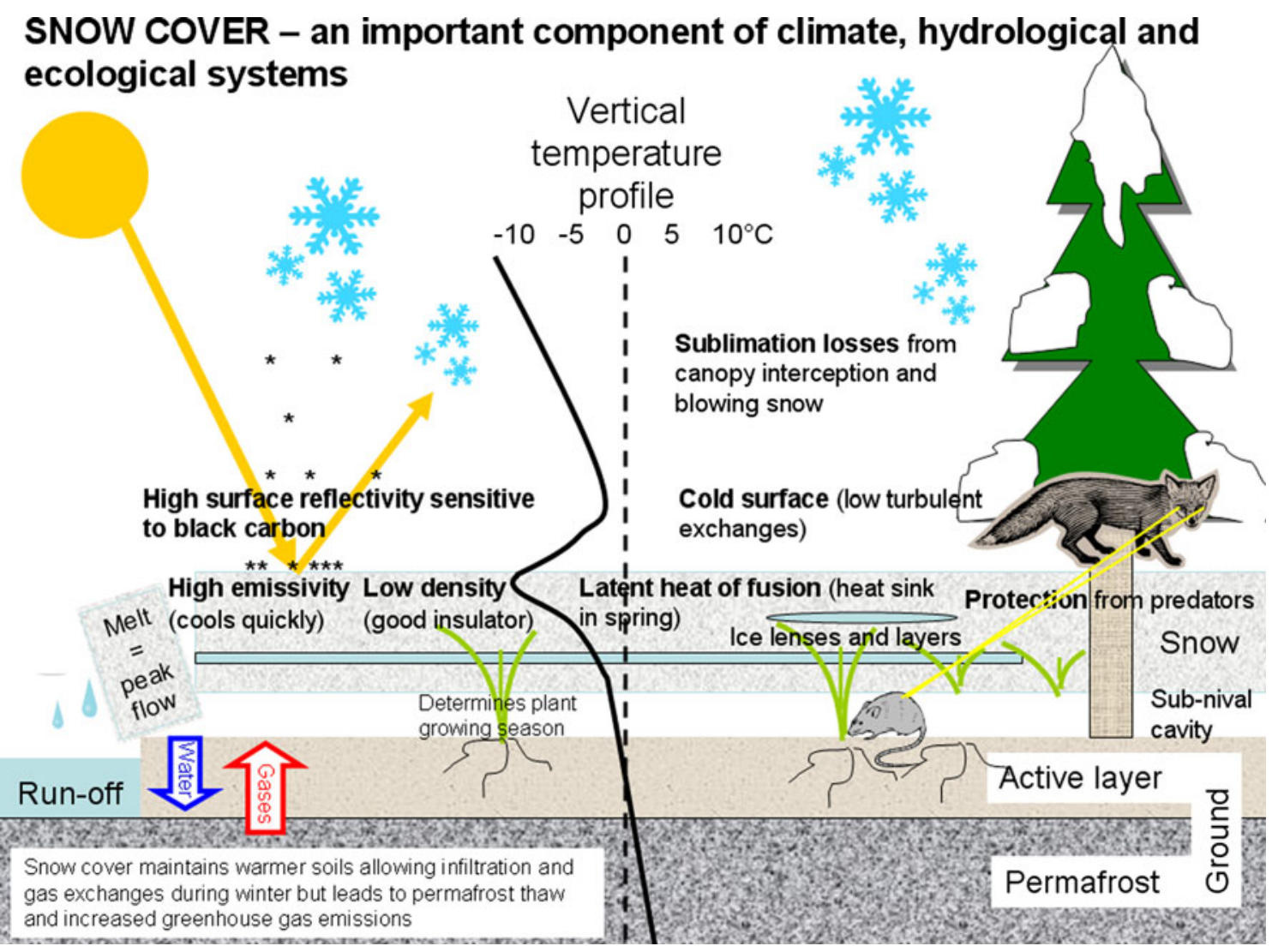

Fig. 1 Schematic illustration outlining the importance of snow on climate, hydrology and ecosystems. The solid black line represents an idealized ground-snow-atmosphere temperature profile to highlight

observed and projected changes in Arctic snow conditions on the climate system, hydrology, ecology, biogeochemical cycling and socio-economics.

\section{THE SURFACE ENERGY BUDGET}

Snow cover has a number of important physical properties that exert an influence on climate or moderate its effects. It has high short-wave albedo, high thermal emissivity, low heat conductivity, large latent heat of fusion and low surface roughness whilst it stores and then rapidly releases water in the melt season. The combination of high albedo (as high as $0.8-0.9$ for dry snow) and low thermal conductivity promotes low surface temperatures and low-level temperature inversions (On-line Supplementary Material A). The low thermal conductivity of snow allows it to insulate the surface from large energy losses in winter, and this has major implications for the energy and moisture fluxes in the near-surface layers. Consequently, the insulating effect has a strong impact on ice growth rates and ice thickness and on the development of seasonally frozen ground and permafrost. The surface energy exchanges are the strong temperature gradients occurring near the snow surface. Source R. Brown and T. V. Callaghan

further modified by the low aerodynamic roughness of snow cover, which can reduce turbulence and, hence, vertical transfer of energy.

The insulating properties of snow affect both the surface and the near-surface temperature regime. Soil surface temperature in mid-winter under $50 \mathrm{~cm}$ of snow may be around zero, whilst the air temperature above the snowpack is as low as $-20^{\circ} \mathrm{C}$ (Pomeroy and Brun 2001). The insulating role of snow prevents deep freezing of near-surface ground, which has important implications for the active layer and for permafrost (see Callaghan et al. 2011c), as well as for the runoff response in spring and for ecological and biogeochemical processes (see below). In the permafrost areas of the Arctic, variations in snow cover depth (rather than surface air temperature) are a major factor controlling temperature variability in the upper $3 \mathrm{~m}$ of soil. For example, Bulygina et al. $(2007,2009,2011)$ observed soil warming trends at some locations where air temperatures were cooling due to increases in winter snow depths.

Changes in snow cover over the Arctic region, particularly in spring, have a strong impact on regional energy budgets owing to the large amount of incoming solar energy reaching the snow surface (e.g. Déry and Brown 
2007). Euskirchen et al. (2007) estimated that a pan-Arctic reduction in snow cover of 0.22 day year $^{-1}$ over the 1970-2000 period of warming contributed an additional $0.8 \mathrm{~W} \mathrm{~m}^{-2}$ per decade of energy. Their simulation also showed evidence of regional asymmetry in Arctic snowalbedo feedback with stronger heating contributions over the North American sector from loss of snow cover. Fernandes et al. (2009) highlighted the importance of snow metamorphism (or ageing) in the albedo feedback with their satellitebased analysis showing that snow metamorphism was as important as loss of snow cover in determining the total terrestrial snow-albedo feedback over Eurasia.

\section{THE ATMOSPHERIC MOISTURE BUDGET}

The atmospheric moisture budget is changing and will continue to evolve in response to a warming climate, changes in sea ice and snow cover and altered atmospheric circulation (Rawlins et al. 2010). Increased winter snowfall over land areas may keep soil moisture levels higher in spring, working with increased precipitation to promote more evaporation. On the other hand, under a warming climate, earlier loss of the snow cover over Arctic and subArctic lands, by exposing the dark underlying surface, will promote surface heating, and hence, an earlier transition to the summer-type convective precipitation regime over Arctic and sub-Arctic lands (Groisman et al. 1994b). A warmer Arctic atmosphere also provides more energy for sublimation. King et al. (2008) estimated Arctic blowing snow sublimation losses to be $\sim 20 \%$ of annual snowfall.

A number of studies have shown that large-scale snow cover anomalies can play a significant role in global scale atmospheric circulations that act over timescales of seasons to years (Groisman et al. 1994a: Gong et al. 2004; Fletcher et al. 2009a, b). For example, there is evidence both from models (e.g. Walland and Simmonds 1997) and observations (Clark and Serreze 2000) that variability in Eurasian snow cover extent modulates atmospheric circulation patterns over the North Pacific Ocean.

Simulations from most coupled GCMs point to intensification of the northern high-latitude freshwater cycle through the twenty-first century (e.g. Holland et al. 2006; Kattsov et al. 2007). A warmer atmosphere carries more water vapour and with efficient precipitation-generating mechanisms (convergence and uplift), precipitation increases. The regional and seasonal variability in sources of moisture for precipitation are described in On-line Supplementary Material B. Whilst evaporation also increases, the precipitation change dominates such that there is an increase in net precipitation and hence river discharge.

\section{THE ROLE OF SNOW COVER IN THE SEASONAL HYDROLOGICAL CYCLE AND EXPECTED CHANGES}

Snow cover has a direct impact on the hydrological cycle in its redistribution of water between cold and warm seasons, with limited water availability during the cold season and an abundance of water during snowmelt. The snow-generated runoff in the Arctic drainage basin is up to $75 \%$ of total annual flow in some northern regions of Siberia and North America (Woo 1980). The indirect snow cover impact has its effects on the surface energy budget. That is, on the latent heat flux to the atmosphere (suppressed by low surface temperatures associated with snow cover and the absence of transpiration) and to the soil (by intercepting precipitation and meltwater and sending a significant part downstream during the snowmelt period instead of contributing to the base flow; Dingman 2002). Therefore, future variations in snow accumulation may dramatically change the hydrological regime of the Arctic (Adam et al. 2009) but there will be regional variations (On-line Supplementary Material B).

Changes in streamflow will be expressed mostly through the high and low flows. At present, spring floods usually represent the highest flow of the year, generated by rapid melting of the snowpack. A shortened snow accumulation season interrupted by mid-winter melt events will diminish the water supply and moderate its rate of delivery. Streamflow data from northern Canada show that there are detectable trends towards an earlier and decreased spring freshet (the peak spring runoff from snowmelt) (Aziz and Burn 2006).

Snow is currently the principal promoter of river flow, but in the future the number and magnitude of rainfall events may increase, whilst the contribution of snow may decline, notably in the sub-Arctic. Small basins with polar desert conditions may find a total cessation of their summer flow except during heavy rains. The seasonal flow pattern may then be replaced by a pluvial or a nivo-pluvial regime.

Reduced snow accumulation, earlier snow melt and increased evaporation (and sublimation) have consequences for seasonal and longer term storage of water and ice. Many late-lying and semi-permanent snowbanks will shrink or disappear from the Arctic landscape. Snow storage on glaciers will change with negative consequences for their mass balance (Sharp et al. 2011). The loss of snowbeds will lead to the demise of many patchy wetlands and the deterioration of others in the Arctic that depend on the late-lying snow to sustain wetland saturation (e.g. Woo and Guan 2006). However, thawing permafrost and associated thermokarst could provide a new source of water. The critically important balance between the two processes is unknown, and areas of drying tundra as well as of increased waterlogging are both being reported (AMAP 2011). 


\section{ECOLOGICAL PROCESSES AND THE ROLE OF SNOW COVER}

Snow is probably one of the most important climatic drivers affecting Arctic biology and its environment (Callaghan et al. 2011a and references therein).

Interactions between snow and vegetation are complex. Whereas, vegetation has strong and complex influences on the accumulation and ablation of snow (Pomeroy et al. 2006), snow provides protection for vegetation from extreme low temperatures, large temperature fluctuations, ice crystal blast, desiccation and herbivory.

Vegetation affects the vertical profile of a snow cover. Snow falling onto shrubs and trees is partitioned into interception by the canopy and throughfall to the ground (Hedstrom and Pomeroy 1998). Snow can remain in a forest canopy for some time before being removed by direct unloading, drip of meltwater and sublimation (e.g. Molotch et al. 2007). Vegetation also reduces the horizontal redistribution of snow and can therefore have greater snow depths than open areas. Snow trapping depends on the height, density and distribution of vegetation, all of which are currently changing in some Arctic areas (e.g. Callaghan and Tweedie 2011).

Vegetation can increase or decrease snowmelt rates relative to open areas (e.g. Pomeroy et al. 2006). However, many processes are involved, and the net outcome in the context of vegetation changes is difficult to model (e.g. Bewley et al. 2007). Whereas vegetation can shade snow on the ground from solar radiation, it can also greatly increase the net thermal radiation absorbed by snow (Sicart et al. 2004). Moreover, sun-lit vegetation can have temperatures well in excess of the air and snow temperatures, further increasing the thermal radiation emitted to the snow (Pomeroy et al. 2009).

Snow, in turn, affects vegetation. There is a close relationship between snow distribution and vegetation type (Evans et al. 1989). Exposed areas typically have lowgrowing plants whose forms provide protection from wind abrasion and summer drought stress (Walker et al. 2001). Plants covered by snow in winter often have the capacity to burst bud quickly after snow melt to maximize their use of the short Arctic growing season (Walker et al. 2001). Changes in snow conditions (presented in Callaghan et al. 2011a, b [this issue]) will affect the future distribution of vegetation, biodiversity and productivity. Although remote sensing shows that the Arctic is generally greening (Bhatt et al. 2010), snow manipulation experiments suggest that responses of vegetation to earlier snowmelt timing may not always be an increase in productivity (Starr et al. 2008). However, in the longer term, when species with more southern distributions invade, the system is likely to become more productive (Sitch et al. 2008; Wolf et al. 2008).
Increases in mid-winter melt events and rainfall instead of snowfall are suggested for some areas (see Callaghan et al. 2011a, references therein). Simulation of such events in the sub-Arctic together with observations of a natural event in winter 2007/2008 has shown that shrub species may be damaged (Bokhorst et al. 2009). The large scale of the natural event (reduced productivity over more than $1400 \mathrm{~km}^{2}$ ) suggests that extreme warming events may moderate (Fig. 2) the long-term trend of shrub expansion into the tundra (Tape et al. 2006). Winter thaw events are an important factor in the decline of one of the most valuable timber species in North America: Alaska yellowcedar (Chamaecyparis nootkatensis). This tree has experienced several waves of death over an area of more than 200 000 ha caused by freezing injury to tree roots (Hennon et al. 2006; Beier et al. 2008) during recent thawing events in late winter.

Interactions between snow and animals are determined by the varying abilities of Arctic species to migrate (Forchhammer et al. 2008; Robinson et al. 2009). Whereas species resident in the Arctic (lemming, musk ox, stoat) and that migrate locally (fox, caribou/reindeer, ptarmigan) will experience varying snow conditions throughout the year, long-distance migrating species (waders, geese, gulls, skuas, terns) are influenced only by the conditions when they arrive at their Arctic breeding grounds in spring. A $10 \%$ decrease in snow cover, advances egg laying by the pink-footed goose (Anser brachyrhynchus) by 5-6 days, corresponding to a $20 \%$ increase in probability of nesting success (Madsen et al. 2007) but climate across the entire range of a species are pivotal in estimating effects taking place in the Arctic.

In addition to the direct effect of snow cover on increased over-winter mortality of populations of resident Arctic species such as musk ox (Ovibos moschatus) (Online Supplementary Material C; Forchhammer et al. 2008), changes in snow cover may also interact with animals in an indirect and delayed manner through interactions across trophic levels (Fig. 3). For example, changes in snow cover determine the resource base for Arctic herbivores: over the period 1970-2006, reindeer calf production in Finland increased by almost one calf per 100 females for each day of earlier snow melt (Turunen et al. 2009). Similarly, the warmer springs and earlier and longer growing seasons of 1996-2005 observed in northeast Greenland have increased the musk ox population there, but the effects were delayed by 1 year (On-line Supplementary Material C; Forchhammer et al. 2008). At Ellesmere Island, years with extensive snow cover delayed vegetation growth, resulting in a halving of the herbivore nutrition-replenishment period, a drastic drop in musk ox and Arctic hare (Lepus arcticus) numbers, and a cascading reduction in the population of their predator, the wolf (Canis lupus) (Mech 2004). 

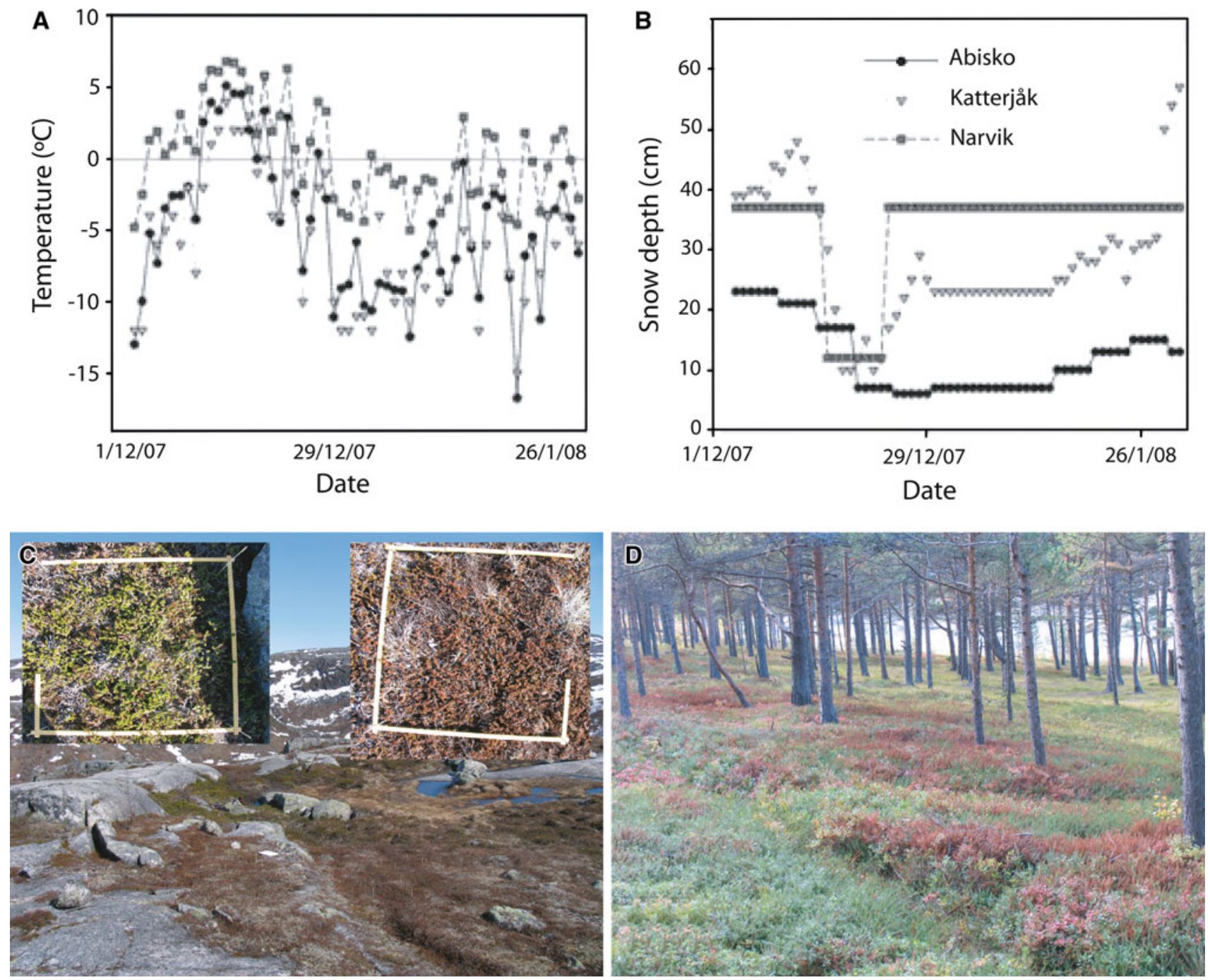

Fig. 2 A mid-winter warming event in December 2007 and its impact on vegetation over $1400 \mathrm{~km}^{2}$ in sub-Arctic Norway and Sweden. Air temperatures (A) increased at three sites along a transect from Narvik, Norway, to Abisko, Sweden $\left(68^{\circ} \mathrm{N}\right)$ for a few days in December and snow melted (B) before returning. The few snow-free

Changes in the micro-topical snow conditions may also influence the dynamics of northern rodents (Kausrud et al. 2008). The hardness of the snowpack is increasing (Johansson et al. 2011). This decreases the available subnivean space, causing a decline in rodent population growth rates. A collapse in rodent population size has cascading effects on predators such as the Tengmalm's owl (Aegolius funereus) (Hörnfeldt et al. 2005) and their alternative prey, such as ground-nesting birds (Kausrud et al. 2008).

Ice crusts, ice layers and rain-on-snow events have been implicated in population crashes of reindeer on Svalbard (Aanes et al. 2000), the near extirpation of Peary's caribou (Rangifer tarandus pearyi) in High Arctic Canada (Barry et al. 2007), population crashes in caribou on the Queen

days resulted in the death of some dwarf shrubs in open, alpine habitats (C) and coastal pine forests (D). Snow remaining in depressions protected vegetation (left insert), whereas unprotected vegetation died (right insert). Source Bokhorst et al. (2009)

Elizabeth Islands, Canadian High Arctic (Miller and Barry 2009) and the deaths of 20000 musk ox on Banks Island in October 2003 (Rennert et al. 2009). The Sámi (Moen 2008; Helle and Kojola 2008) and Nenets (e.g. Bartsch et al. 2010) have experienced the increasing frequency of extreme weather events and effects on reindeer mortality and calf production. Declining polar bear populations are also partly due to changing snow conditions as female polar bears make dens in snow to shelter and give birth to young during winter. Rains early in the breeding season can melt the under-snow lairs and increase cub mortality (Stirling and Smith 2004).

Future warming could be associated with events that cause sudden and dramatic step changes, rather than progressive trends, in both animal and plant biodiversity. 


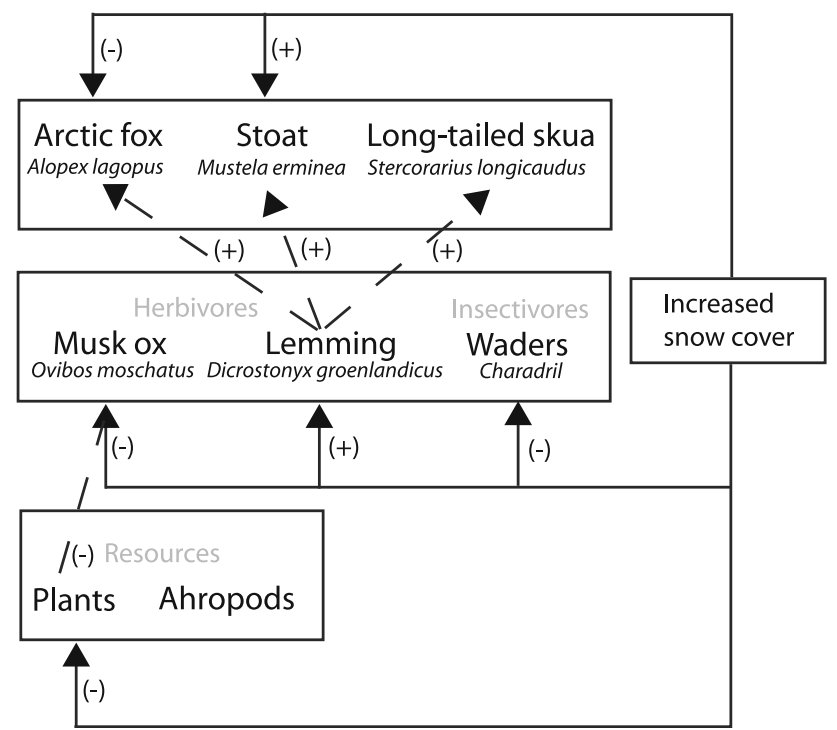

Fig. 3 Schematic overview of the consequences of increased snow cover on the terrestrial vertebrate community at Zackenberg, northeastern Greenland. Arrows indicate potential direct (solid arrows) and indirect (dashed arrows) effects. Modified from Forchhammer et al. (2008)

\section{INTERACTIONS BETWEEN SNOW AND BIOGEOCHEMICAL CYCLES}

Winter respiration of $\mathrm{CO}_{2}$ is a significant portion of the annual carbon budget (e.g. Fahnestock et al. 1998). Snow acts as an insulator and increases ground temperature, which is one of the main drivers of winter respiration rates in the Arctic (Grogan and Jonasson 2006). Experimental increases of snow depth in High Arctic Canada (Nobrega and Grogan 2007) and sub-Arctic Sweden (Larsen et al. 2007) increased ecosystem respiration rates by $60 \%$ and $157 \%$ compared with control plots. Their results suggest that a moderate increase in snow depth can enhance winter respiration sufficiently to alter the ecosystem annual net carbon exchange from a sink to a source, resulting in a net release of $\mathrm{CO}_{2}$ to the atmosphere.

The depth of snow that affects hydrology at the onset of the growing season will have strong impacts on the degree of waterlogging and, hence, the potential emissions of other important greenhouse gases, such as methane $\left(\mathrm{CH}_{4}\right)$ and nitrous oxide $\left(\mathrm{N}_{2} \mathrm{O}\right)$, in that emissions will increase with the extent of waterlogging. Also, the date of snow melt is important for the growing season accumulated uptake of carbon, as solar radiation input is high at this time compared with the period in autumn when the snowpack is formed. Euskirchen et al. (2006) estimated that for each day that the growing season increased across the pan-Arctic region over the period 2001-2100 the carbon drawdown increased by $9.5 \mathrm{~g} \mathrm{C} \mathrm{m}^{-2}$ year $^{-1}$.

\section{GEOCHEMICAL PROCESSES IN THE SNOW COVER}

The effects of heavy metals are many and varied depending on factors such as the particular metal, the organism and the mode of uptake (Dietz et al. 1998). Their greatest toxic impacts occur in animals at the higher trophic levels where bioaccumulation through the food chain can result in high concentrations. The few available data on heavy metal concentrations in snow on ice surfaces in the Russian Arctic seas (e.g. Golubeva 2007; Callaghan et al. 2011a, references therein) mostly show no evidence of pollution, except in areas near the large industrial centers of the Kola Peninsula (Monchegorsk, Nikel) and Siberia (Norilsk) and along the Northern Sea Route.

A significant reduction in on-ice snow volume has led to changes in the size of the storage reservoirs for contaminants such as heavy metals (especially mercury), as well as persistent organic pollutants, such as PCBs (polychlorinated biphenyls) and DDT (Kallenborn et al. 2011). Changes in the size of the storage reservoirs, and in the processes driving these changes, could increase the delivery of heavy metals to the tundra and coastal ecosystems through changes in dry deposition and wet deposition through rainfall and fog. At the same time, heavy metal accumulation in snow cover on drifting ice will decrease, resulting in a redistribution of heavy metal pollution (see On-line Supplementary Material D).

\section{SOCIO-ECONOMIC PROCESSES AND THE ROLE OF SNOW COVER}

Water resources and hydropower will be affected by projected changes in snow cover and duration that will affect the capacity and operations of current and future hydroelectric developments and might resolve some of the rising energy needs (Furgal and Prowse 2008). In areas where winter precipitation is expected to increase (Callaghan et al. 2011a, 2011b [this issue]), an increase in runoff is expected (On-line Supplementary Material E), (Gode et al. 2007). Projected increases in winter rainfall, increased freeze-thaw cycles and increased glacier melt are expected to lead to an enhanced winter snow melt and a decline in winter storage and, hence, a more even runoff over the year (Gode et al. 2007; Furgal and Prowse 2008). This will reduce the need for peak reservoir levels without generating maximum electricity (Gode et al. 2007: On-line Supplementary Material E). Large variation between the results for two GCMs used to provide runoff projections provides a challenge for economic forecasting (On-line Supplementary Material E, Table E2), whilst changes in climate will alter the conditions for the power plants. For 
example, in some regions reservoir capacities may need to be expanded to offset changes in runoff, both for seasonal and total annual runoff. In addition, the construction of hydropower dams needs to take into account the different future projections for ice conditions (Prowse et al. 2011a, b [this issue]).

Transport in the Arctic often depends on snow conditions: snow is required for transport by Arctic residents, particularly Indigenous Peoples, during winter whereas it can be problematic for transport by rail, road and air. Rising temperatures in the Arctic, particularly decreases in very cold days, later onset of seasonal freezes and earlier onset of seasonal thaws projected for many Arctic areas, could mean reduced costs of snow and ice control, as is the case in the mid-latitudes with seasonal snow cover. A projected shortening of the snow cover season over most of the Arctic will decrease the operational period of winter road networks that are important for low cost re-supply of many northern communities in Canada (Furgal and Prowse 2008) and shorten the period that snowmobiles can be used for hunting and reindeer herding.

Forestry will be affected by changing snow conditions and evidence is already accumulating of detrimental impacts. Where precipitation in the boreal region is most abundant (eastern Canada, western Russia and Fennoscandia), an increase in temperature can often result in increased growth in healthy trees (Saxe et al. 2001) and a northward and upward extension in range as projected by many models (see Callaghan et al. 2011a, references therein). However, the moisture regime in much of the boreal region is only marginally suitable for forest growth and development. Consequently, reduced growth of boreal trees during warming was widespread over much of the past century in nearly all regions and tree species (see Callaghan et al. 2011a, references therein). Under warmer climatic conditions, the northern treeline would probably not advance uniformly into regions that were formerly too cold (as generally perceived), but would advance in a fragmented manner by occupying parts of the landscape with sufficient moisture, for example from snow accumulations.

New direct experimental results demonstrate that at least some boreal evergreen conifers largely grow by moisture supplied from winter snowpack melt (Yarie 2008). In most of the boreal forest region, temperature increases have made the snow accumulation season shorter, so that less of the annual water budget is introduced into the ground in the spring pulse of snowmelt. Broadleaf trees can use the variable summer rains more effectively than most conifers, so this change in the seasonal type of moisture (less snow, more rain) now favours the broadleaf trees over conifers (Juday 2009). Boreal broadleaf tree ecosystems are characterized by less storage of carbon than conifer-dominated forests and the coniferous trees are more widely used in the timber industry.

In contrast to the benefits of a deep snow cover by providing water, heavy snowfall causes damage to forests in Finland. A modelling assessment of risk projected that compared with the baseline period 1961-1990, the amount of damaging snowfalls and risk of snow-induced forest damage will decrease, particularly in the north of Finland (Kilpelainen et al. 2010).

Snow anomalies, as they interact with rising temperatures, also affect the insects that feed on boreal tree species and these can damage millions of cubic metres of timber (On-line Supplementary Material F).

Natural hazards related to snow result mainly from avalanches. Snow avalanches are well understood and safety measures are taken in many alpine regions, but the distribution, frequency and impacts are less well known in the Arctic. Likely increases in snowfall amounts during extreme events may change avalanche potential in some regions of the Arctic. A number of physically based snowpack models exist that can be used to estimate change in avalanche potential (e.g. Lehning et al. 1999). However, to date, there has been no systematic assessment of change in avalanche potential over the Arctic in response to climate change as the snowpack models require very detailed site-specific input data (e.g. SNTHERM; Lazar and Williams 2008).

Slush torrents in the Arctic (Fig. 4) are events that occur within minutes but often have return frequencies over decades and thus are difficult to document (Bull et al. 1995; Gude and Scherer 1995). However, these are a major driver of the geomorphology of northern mountain landscapes. Any increased frequency due to an intensification of the spring melt could have important local impacts.

Tourism and leisure pursuits are based on scenery (iceand snow-scapes, mountains and tundra, vistas), unique Arctic wildlife (including guided hunting) and traditional indigenous cultures. Climate change and its effects such as changing snow conditions could dramatically alter all of these, but snow conditions and their impacts on tourism are not well addressed in the climate change literature.

Snow accumulation, duration and consistency will have an effect on access to attractions and snow-based activities such as dog sledding, skiing, reindeer sledding, skidoo touring and winter activities in general. Greater snow accumulation leads to access difficulties, but also to new opportunities for snow-based activities (Dawson et al. 2007). Shorter snow duration leads to seasonal challenges for some activities. Change in consistency of the snowpack, including more tundra ice versus snow leads to winter tourism challenges (such as for dog sledding, skidoo touring), and the unpredictability of snow conditions (e.g. winter thaws) could lead to negative experiences for 


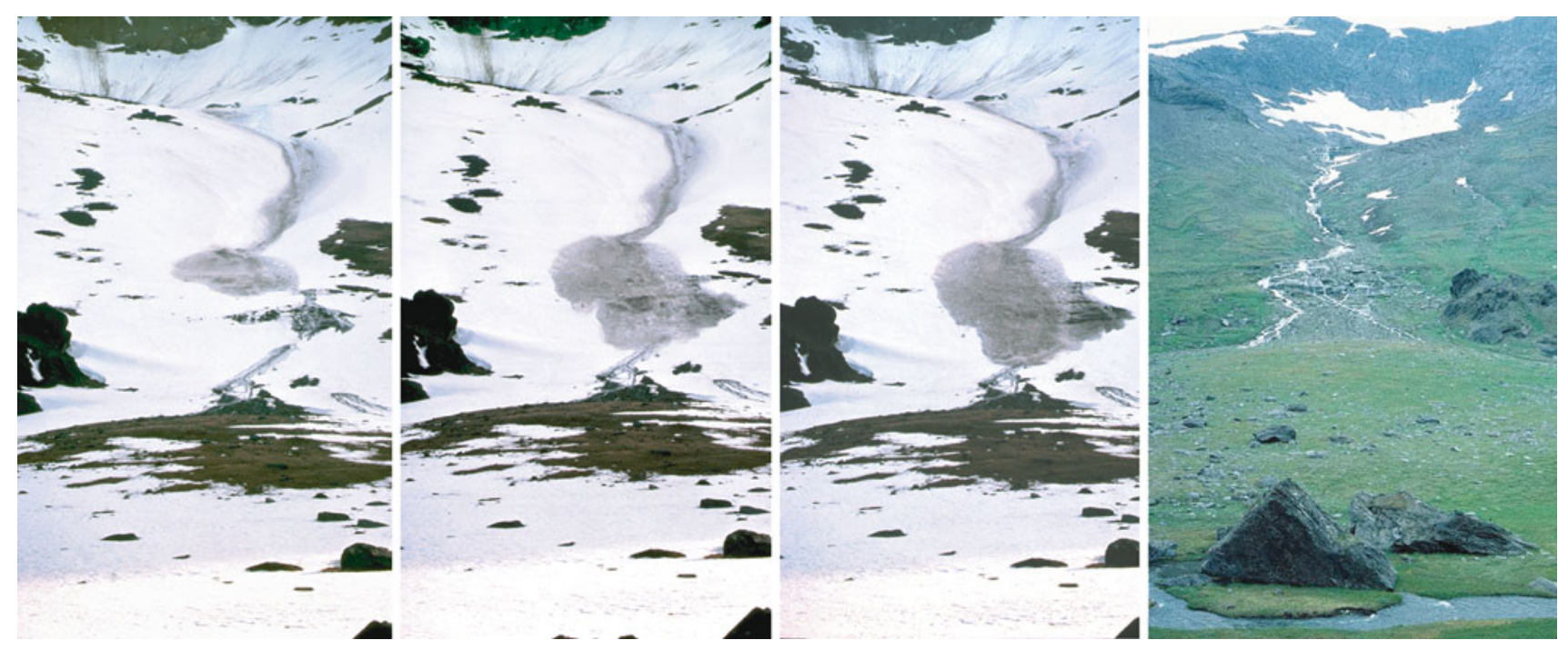

Fig. 4 Images based on a rare recording of a slush torrent in June 1996 from sub-Arctic Sweden. The first three images show the result of increased saturation of the snowpack and then release of a large amount of water. The fourth image shows the valley in spring with a fan formed by such short-lived events over millennia. (Photo: Martin Gude, University of Jena, Germany and Dieter Scherer, Technical University Berlin, Germany)

that hampers foraging throughout winter is probably more important than actual snow accumulation in open, high pasture areas. In contrast, mould formation that is harmful to animals and can kill calves occurs especially after mild, rainy autumns, when the soil does not have time to freeze before the snow falls (Turunen et al. 2009).

As changes in climate and snow conditions render reindeer herding more insecure and less economically productive, there is likely to be a climate-induced shift from a mixed economy to a market-based economy. This would have significant cultural implications for indigenous peoples in the Arctic, even though the current general lowprofit situation does not seem to limit the cultural value of herding (e.g. Forbes 2008).

Human health status reflects the complex interaction of all the individual, social, cultural, nutritional and socio-economic factors together with the environment (e.g. landscape and snow cover affect the health and well-being of Arctic populations). There are two categories of climate-related effects on human health: direct impacts (such as temperature and ultraviolet light), and indirect impacts (such as climate-induced changes in wildlife and zoonotic diseases; Parkinson and Butler 2005). Other important issues include contaminant concentrations which can compromise the immune system in animals and humans and thus increase risk of disease (Hansen et al. 2008), traditional food security, community adaptation to stress and community-based monitoring. The impact of climate change on wildlife species is critical to the diet of indigenous residents following a traditional way of life. 
Changes in climate, such as changes in snow conditions, are likely to add to the ongoing negative impacts of general societal change and modernization in the Arctic (Bjerregaard et al. 2004). The psychosocial stress is reflected in alcohol abuse, violence and suicide, and these have all been shown to be associated with changes in lifestyle and living conditions (Curtis et al. 2005) that are affected by the impacts of changing snow conditions on traditional activities (subsistence hunting and gathering as well as recreational activities). Currently, many Arctic indigenous and other resident populations are experiencing high mortality rates from injury and suicide and higher hospitalization rates for infants with pneumonia, meningitis and respiratory infections (Heikkinen et al. 2008; Meyer et al. 2008). Wintertime mortality and morbidity will decrease with higher environmental temperatures (Näyhä 2005). However, extreme weather events, such as storms including blizzards and weather variability, will probably cause adverse health outcomes, especially for the elderly, those with chronic diseases, and children.

Reindeer herding includes many hazardous tasks in potentially dangerous climates and environments. Most Sámi reindeer herding men spend more than $800 \mathrm{~h}$ per year on snowmobiles (Daerga et al. 2004) and the number of deaths caused by snowmobiles and terrain vehicles tripled between 1961 and 2000 (Hassler et al. 2004). Reductions in snow cover would eventually lead to less use of snowmobiles and, perhaps, a shift away from reindeer herding in a warmer Arctic. This would result in fewer accidents. However, the psychological results might offset this, and adaptation during the transition period of changing snow conditions could be particularly difficult.

\section{CONCLUSIONS}

Changing Arctic snow climate is having widespread impacts and future changes will probably intensify these. Impacts can be beneficial or deleterious depending on the snow cover sensitivities involved. As snow plays a vital role in the climate system, for example through its reflectivity and by affecting moisture and hydrology, changes in snow conditions will lead to changes in climate in the Arctic and other regions. Diminished spring floods and a longer snow-free season increase the potential for evaporation and threats to wetlands, but this may be offset by new sources of water from thawing permafrost and associated thermokarst.

Snow-vegetation interactions are expected to play an important role in the future evolution of northern hydrology and thermal regimes. A shorter SCD is likely to increase plant productivity and carbon capture where soil moisture is adequate. However, reductions in the amount of water stored in the winter snowpack are already increasing the moisture stress of northern coniferous forests in summer with commercial implications. Winter thaws and rainon-snow events that are projected to increase in frequency are already damaging vegetation and Arctic animal populations and will lead to additional challenges for commercial reindeer herding, forestry and conservation. In contrast, longer snow-free periods are likely to lead to increased breeding success for some animal species.

Changes in the snow-scape and iconic wildlife species are likely to affect Arctic tourism which has relatively little ability to diversify. As Arctic Indigenous Cultures and traditional land use are strongly dependent on snow conditions, changes in these conditions could affect the livelihoods, health and well-being of Arctic residents.

Reduced SCD is leading to changes in the storage reservoirs for contaminants and a redistribution of heavy metal pollution. Although snow-related hazards could increase in areas with projected increases in annual maximum snow accumulation, increased winter precipitation and a more even seasonal distribution of runoff may prove beneficial to the hydropower industry.

Acknowledgments The authors wish to thank the various national funding agencies that made this review possible, specifically the Swedish Environmental Protection Agency (grant number 08/210) and the Swedish Research Council FORMAS (grant number 204-2009-45) who helped directly support this publication. The authors also gratefully acknowledge the Arctic Monitoring and Assessment Program Secretariat and the SWIPA Integration Team in helping to produce the original SWIPA report and the various contributing SWIPA chapter authors. Finally, the authors thank reviewers of the SWIPA snow chapter, particularly Barry Goodison.

\section{REFERENCES}

Aanes, R., B.E. Saether, and N.A. Oritsland. 2000. Fluctuations of an introduced population of Svalbard reindeer: the effects of density dependence and climatic variation. Ecography 23: 437-443.

Adam, J.C., A.F. Hamlet, and D.P. Lettenmaier. 2009. Implications of global climate change for snowmelt hydrology in the $21 \mathrm{st}$ century. Hydrologic Processes 23: 962-972.

AMAP. 2011. Snow, water, ice and permafrost in the arctic (SWIPA). Oslo: Arctic Monitoring and Assessment Programme (AMAP), 542.

Aziz, A.O.I., and D.H. Burn. 2006. Trends and variability in the hydrological regime of the Mackenzie River Basin. Journal of Hydrology 319: 282-294.

Barry, R.G., R. Armstrong, T. Callaghan, J. Cherry, S. Gearheard, A. Nolin, D. Russell, and C. Zöckler. 2007. Snow. In Global outlook for Ice \& Snow, ed. UNEP. ISBN: 978-92-807-2799-9.

Bartsch, A., T. Kumpula, B.C. Forbes, and F. Stammler. 2010. Detection of snow surface thawing and refreezing in the Eurasian Arctic using QuikSCAT: Implications for reindeer herding. Ecological Applications 20: 2346-2358.

Bewley, D., J.W. Pomeroy, and R.L.H. Essery. 2007. Solar radiation transfer through a subarctic shrub canopy. Arctic, Antarctic, and Alpine Research 39: 365-374. 
Beier, C.M., S.E. Sink, P.E. Hennon, D.V. D'Amore, and G.P. Juday. 2008. Twentieth-century warming and the dendroclimatology of declining yellow-cedar forests in southeastern Alaska. Canadian Journal of Forest Research 38: 1319-1334.

Bhatt, U.S., D.A. Walker, M.K. Raynolds, J.C. Comiso, H.E. Epstein, G.S. Jia, R. Gens, J.E. Pinzon, et al. 2010. Circumpolar Arctic tundra vegetation change is linked to sea ice decline. Earth Interactions 14: 1-20.

Bjerregaard, P., T.K. Young, E. Dewailly, and S.O.E. Ebbesson. 2004. Indigenous health in the Arctic: an overview of the circumpolar Inuit population. Scandinavian Journal of Public Health 32: 390-395.

Bokhorst, S., J.W. Bjerke, H. Tömmervik, T.V. Callaghan, and G.K. Phoenix. 2009. Winter warming events damage sub-Arctic vegetation: consistent evidence from an experimental manipulation and a natural event. Journal of Ecology 97: 1408-1415.

Bull, W.B., P. Schlyter, and S. Brogaard. 1995. Lichenometric analysis of the Kärkerieppe slush-avalanche fan, Kärkevagge, Sweden. Geografiska Annaler 77A: 231-248.

Bulygina, O.N., N.N. Korshunova, and V.N. Razuvaev. 2007. Changes in snow cover characteristics in recent decades. In Proceedings of the RIHMI-WDC, vol. 173, 54-66 (in Russian).

Bulygina, O.N., V.N. Razuvaev, and N.N. Korshunova. 2009. Changes in snow cover over Northern Eurasia in the last few decades. Environmental Research Letters 4: 045026. doi: 10.1088/1748-9326/4/4/045026.

Bulygina O.N., P. Ya. Groisman, V.N. Razuvaev, and N.N. Korshunova. 2011. Changes in snow cover characteristics over northern Eurasia since 1966. Environmental Research Letters 6:045204. doi:10.1088/1748-9326/6/4/045204.

Callaghan, T.V., and C.E. Tweedie. 2011. Multi-Decadal Changes in Tundra Environments and Ecosystems: The International Polar Year Back to the Future Project. Ambio 40: 555-716.

Callaghan, T.V., M. Johansson, R.D. Brown, P. Ya. Groisman, N. Labba, and V. Radionov. 2011a. Chapter 4. Changing snow cover and its impacts. In Snow, water, ice and permafrost in the Arctic (SWIPA). Oslo: Arctic Monitoring and Assessment Programme (AMAP).

Callaghan, T.V., M. Johansson, R.D. Brown, P. Ya. Groisman, N. Labba, and V. Radionov et al. 2011b. The changing face of Arctic snow cover: A synthesis of observed and projected changes. In Arctic cryosphere-Changes and impacts, ed. T.V. Callaghan, M. Johansson, and T.D. Prowse. Ambio 40(S1). doi: 10.1007/s13280-011-0212-y.

Callaghan, T.V., M. Johansson, O. Anisimov, H.H. Christiansen, A. Instanes, V. Romanovsky, and S. Smith. 2011c. Chapter 5: Changing permafrost and its impacts. In Snow, water, ice and permafrost in the Arctic (SWIPA). Oslo: Arctic Monitoring and Assessment Programme (AMAP).

Clark, M.P., and M.C. Serreze. 2000. Effects of variations in east Asian snow cover on modulating atmospheric circulation over the North Pacific Ocean. Journal of Climate 13: 3700-3710.

Curtis, T., S. Kvermmo, and P. Bjerregaard. 2005. Changing living conditions, life style and health. International Journal of Circumpolar Health 64: 442-450.

Daerga, L., A. Edin-Liljegren, and P. Sjölander. 2004. Work-related musculoskeletal pain among reindeer herding Sami in Sweden-a pilot study on causes and prevention. International Journal of Circumpolar Health 63: 343-348.

Dawson, J., P.T. Maher, and D. Scott Solcombe. 2007. Climate change, marine tourism, and sustainability in the Canadian Arctic: Contributions from Systems and complexity approaches. Tourism in Marine 4: 69-83.

Déry, S.J., and R.D. Brown. 2007. Recent Northern Hemisphere snow cover extent trends and implications for the snow-albedo feedback. Geophysical Research Letters 34: L22504. doi: 10.1029/2007GL031474,2007.

Dietz, R., J. Pacyna, and D.J. Thomas. 1998. Heavy Metals. Chapter 7 , In AMAP Assessment Report: Arctic Pollution Issues. Arctic Monitoring and Assessment programme (AMAP). Norway: Oslo.

Dingman, S.L. 2002. Physical hydrology, 2nd edition. Chapter 5: snow and snowmelt, 159-209. Upper Saddle River: Prentice Hall.

Euskirchen, E.S., A.D. McGuire, D.W. Kicklighter, Q. Zhuang, J.S. Clein, R.J. Dargaville, D.G. Dye, J.S. Kimball, et al. 2006. Importance of recent shifts in soil thermal dynamics on growing season length, productivity, and carbon sequestration in terrestrial high-latitude ecosystems. Global Change Biology 12: 731-750.

Euskirchen, E.S., A.D. Mcguire, and F.S. Chapin III. 2007. Energy feedbacks of northern high-latitude ecosystems to the climate system due to reduced snow cover during 20th century warming. Global Change Biology 13: 2425-2438.

Evans, B.M., D.A. Walker, C.S. Benson, E.A. Nordstrand, and G.W. Petersen. 1989. Spatial interrelationships between terrain, snow distribution and vegetation patterns at an arctic foothills site in Alaska. Holarctic Ecology 12: 270-278.

Fahnestock, J.T., M.H. Jones, P.D. Brooks, D.A. Walker, and J.M. Welker. 1998. Winter and early spring CO2 efflux from tundra communities of northern Alaska. Journal of Geophysical Research - Atmospheres 103(D22): 29023-29027.

Fernandes, R., H. Zhao, X. Wang, J. Key, X. Qu, and A. Hall. 2009. Controls on Northern Hemisphere snow albedo feedback quantified using satellite Earth observations. Geophysical Research Letters 36: L21702. doi:10.1029/2009GL040057,2009.

Fletcher, C.G., P.J. Kushner, A. Hall, and X. Qu. 2009a. Circulation responses to snow albedo feedback in climate change. Geophysical Research Letters 36: L09702. doi:10.1029/2009GL038011.

Fletcher, C.G., S.C. Hardiman, P.J. Kushner, and J. Cohen. 2009b. The dynamical response to snow cover perturbations in a large ensemble of atmospheric GCM integrations. Journal of Climate 22: 1208-1222. doi:10.1175/2008JCLI2505.1.

Forbes, B.C. 2008. Equity, vulnerability and resilience in socialecological systems: a contemporary example from the Russian Arctic. Research in Social Problems and Public Policy 15: 203-236.

Forchhammer, M.C., N.M. Schmidt, T.T. Høye, T.B. Berg, D.K. Hendrichsen, and E. Post. 2008. Population dynamical responses to climate change. Advances in Ecological Research 40: $391-420$.

Furgal, C. and T.D. Prowse. 2008. Northern Canada. In From impacts to adaptation: canada in a changing climate 2007, ed. D.S. Lemmen, F.J. Warren, J. Lacroix, and E. Busch, 57-118. Ottawa: Government of Canada.

Gode, J., J. Axelsson, S. Eriksson, K. Holmgren, G. Hovsenius, E. Kjellström, P. Larsson, L. Lundström, and G. Persson. 2007. Tänkbara konsekvenser för energisektorn av klimatförändringar-Effekter, sårbarhet, anpassning. [Possible consequences of climate change on the energy sector-effects, vulnerability and adaptation] Elforsk rapport 07:39 (in Swedish).

Golubeva, N.I. 2007. Pollution of Arctic atmosphere by toxic heavy metals. Biology and Oceanography of Northern Sea Route. The Barents and Kara Seas. Moscow: Nauka, 173-189 (in Russian).

Gong, G., D. Entekhabi, J. Cohen, and D. Robinson. 2004. Sensitivity of atmospheric response to modeled snow anomaly characteristics. Journal of Geophysical Research 109: D06107. doi: 10.1029/2003JD004160.

Grogan, P., and S. Jonasson. 2006. Ecosystem $\mathrm{CO}_{2}$ production during winter in a Swedish subarctic region: the relative importance of climate and vegetation type. Global Change Biology 12: $1479-1495$. 
Groisman, P.Ya., T.R. Karl, R.W. Knight, and G.L. Stenchikov. 1994a. Changes of snow cover, temperature, and the radiative heat balance over the Northern Hemisphere. Journal of Climate 7: 1633-1656.

Groisman, P.Ya., T.R. Karl, and R.W. Knight. 1994b. Observed impact of snow cover on the heat balance and the rise of continental spring temperatures. Science 263: 198-200.

Gude, M., and D. Scherer. 1995. Snowmelt and slush torrentsPreliminary report from a field campaign in Kärkevagge, Swedish Lappland. Geografiska Annaler 77A: 199-206.

Hansen, J.C., B. Deutch, and J.Ø. Odland. 2008. Dietary Transition and Contaminants in the Arctic; Emphasis on Greenland. International Journal of Circumpolar Health (suppl 2), 91 pp.

Hassler, S., P. Sjölander, R. Johansson, H. Grönberg, and L. Damber. 2004. Fatal accidents among reindeer herding Sami in Sweden. International Journal of Circumpolar Health 63: 384-388.

Hedstrom, N.R., and J.W. Pomeroy. 1998. Measurement and modelling of snow interception in the boreal forest. Hydrological Processes 12: 1611-1625.

Heikkinen, T., R. Österback, V. Peltola, T. Jartti, and R. Vainionpää. 2008. Human metapneumovirous infections in children. Emerging Infectious Diseases Journal 14: 101-106.

Helle, T., and I. Kojola. 2008. Demographics in an alpine reindeer herd: effects of density and winter weather. Ecography 31: 221-230.

Hennon, P., D. D'Amore, D. Wittwer, A. Johnson, P. Schaberg, G. Hawley, C. Beier, S. Sink, and G. Juday. 2006. Climate warming. Reduced snow, and freezing injury could explain the demise of yellow-cedar in southeast Alaska, USA. World Resource Review 18: 427-445.

Holland, M.M., J. Finnis, and M.C. Serreze. 2006. Simulated Arctic Ocean freshwater budgets in the $20^{\text {th }}$ and $21^{\text {st }}$ centuries. Journal of Climate 19: 6221-6242.

Hörnfeldt, B., T. Hipkiss, and U. Eklund. 2005. Fading out of vole and predator cycles? Proceedings of the Royal Society B: Biological Sciences B 272: 2045-2049.

Johansson, C. V.A. Pohjola, T.V. Callaghan, and C. Jonasson. 2011. Changes in snow characteristics in sub-Arctic Sweden. In: Multidecadal changes in tundra environments and ecosystems: The international polar year back to the future Project, ed. T.V. Callaghan, and C.E. Tweedie. Ambio 40: 555-574.

Juday, G.P. 2009. Boreal forests and climate change. In: Oxford companion to global change, ed. A. Goudie, and D. Cuff. Oxford: Oxford University Press. ISBN: 978-0-19-532488-4.

Kallenborn, R. R. Macdonald, C. Halsall, J. Pawlak, and T. Bidleman. 2011. Contaminant pathways and change in the cryosphere. Chapter 11.3. In Snow, water, ice and permafrost in the Arctic (SWIPA). Oslo: Arctic Monitoring and Assessment Programme (AMAP)

Kattsov, V.M., J.E. Walsh, W.L. Chapman, V.A. Govorkova, T.V. Pavlova, and X. Zhang. 2007. Simulation and projection of Arctic freshwater budget components by the IPCC AR4 Global Climate Models. Journal of Hydrometeorology 8: 571-589.

Kausrud, K.L., A. Mysterud, H. Steen, J.O. Vik, E. Østbye, B. Cazelles, E. Framstad, A.M. Eikeset, et al. 2008. Linking climate change to lemming cycles. Nature 456: 93-97.

Kilpelainen, A., H. Gregow, H. Strandman, S. Kellomaki, A. Venalainen, and H. Peltola. 2010. Impacts of climate change on the risk of snow-induced forest damage in Finland. Climatic Change 99: 193-209.

King J.C., J.W. Pomeroy, D.M. Gray, C. Fierz, P.M.B. Föhn, R.J. Harding, R.E. Jordan, E. Martin, and C. Plüss. 2008. Snowatmosphere energy and mass balance. In: Snow and climate ed. R.L. Armstrong, and E. Brun, 70-124. Cambridge: Cambridge University Press.
Kumpula, J., and A. Colpaert. 2003. Effects of weather and snow conditions on reproduction and survival of semi- domesticated reindeer (R.t. tarandus). Polar Research 22: 225-233.

Larsen, K.S., P. Grogan, S. Jonasson, and S. Michelsen. 2007. Respiration and microbial dynamics in two subarctic ecosystems during winter and spring thaw: effects of increased snow depth. Arctic, Antarctic, and Alpine Research 39: 268-276.

Lazar, B., and M. Williams. 2008. Climate change in western ski areas: Potential changes in the timing of wet avalanches and snow quality for the Aspen ski area in the years 2030 and 2100. Cold Regions Science and Technology 51: 219-228.

Lehning, M., P. Bartelt, R.L. Brown, T. Russi, U. Stöckli, and M. Zimmerli. 1999. Snowpack model calculations for avalanche warning based upon a new network of weather and snow stations. Cold Regions Science and Technology 30: 145-157.

Madsen, J., M. Tamstorf, M. Klaassen, N. Eide, C. Glahder, F. Rigét, H. Nyegaard, and F. Cottaar. 2007. Effects of snow cover on the timing and success of reproduction in high-Arctic pink-footed geese Anser brachyrhynchus. Polar Biology 30: 1363-1372.

Mech, L.D. 2004. Is climate affecting wolf populations in the high Arctic? Climatic Change 67: 87-93.

Meyer, A., K. Ladefoged, P. Poulsen, and A. Koch. 2008. Populationbased survey of invasive bacterial diseases in Greenland, 1995-2004. Emerging Infectious Diseases Journal 14: 16-19.

Moen, J. 2008. Climate Change: Effects on the Ecological Basis for Reindeer Husbandry in Sweden. Ambio 37: 304-311.

Miller, F.L., and S.J. Barry. 2009. Long-term control of peary caribou numbers by unpredictable, exceptionally severe snow or ice conditions in a non-equilibrium grazing system. Arctic 62: $175-189$.

Molotch, N.P., P.D. Blanken, M.W. Williams, A.A. Turnipseed, R.K. Monson, and S.A. Margulis. 2007. Estimating sublimation of intercepted and sub-canopy snow using eddy covariance systems. Hydrological Processes 21: 1567-1575.

Näyhä, S. 2005. Environmental temperature and mortality. International Journal of Circumpolar Health 64: 451-458.

Nobrega, S., and P. Grogan. 2007. Deeper snow enhances winter respiration from both plant-associated and bulk soil carbon pools in birch hummock tundra. Ecosystems 10: 419-431.

Parkinson, A.J., and J.C. Butler. 2005. Potential impacts of climate change on infectious diseases in the Artic. International Journal of Circumpolar Health 64: 478-486.

Pomeroy, J.W. and E. Brun. 2001. Physical properties of snow Chapter 2, In Snow ecology, ed. H. G. Jones. Cambridge: Cambridge University Press.

Pomeroy, J.W., D.S. Bewley, R.L.H. Essery, N.R. Hedstrom, T. Link, R.J. Granger, J.-E. Sicart, C.R. Ellis, and J.R. Janowicz. 2006. Shrub Tundra Snowmelt. Hydrological Processes 20: 923-941.

Pomeroy, J.W., D. Marks, T. Link, C. Ellis, J. Hardy, A. Rowlands, and R. Granger. 2009. The impact of coniferous forest temperature on incoming longwave radiation to melting snow. Hydrological Processes 23: 2513-2525.

Prowse, T.D., K. Alfredsen, S. Beltaos, B. Bonsal, C. Duguay, A. Korhola, J. McNamara, W.F. Vincent et al. 2011. Changing lake and river ice regimes: Trends, effects and implications. In Snow, water, ice and permafrost in the Arctic (SWIPA). Oslo: Arctic Monitoring and Assessment Programme (AMAP).

Prowse, T.D., K. Alfredsen, S. Beltaos, B.R. Bonsal, C. Duguay, A. Korhola, J. McNamara, R. Pienitz, et al. 2012. Past and future changes in Arctic lake and river ice. In Arctic cryosphereChanges and impacts, ed. T.V. Callaghan, M. Johansson, and T.D. Prowse. Ambio 40(S1). doi:10.1007/s13280-011-0216-7.

Rawlins, M.A., M. Steele, M.M. Holland, J.C. Adams, J.E. Cherry, et al. 2010. Analysis of the Arctic system for freshwater cycle intensification: Observations and expectations. Journal of Climate 23: 5715-5737. 
Rennert, K.J., G. Roe, J. Putkonen, and C.M. Bitz. 2009. Soil thermal and ecological impacts of rain on snow events in the circumpolar Arctic. Journal of Climate 22: 2302-2315.

Riseth, J.Å., H. Tømmervik, E. Helander-Renvall, V. Pohjola, N.T. Labba, N. Labba, E.A. Niia, H. Kuhmunen, A. Schanche, C. Jonasson, C. Johansson, L.-E. Sarri, J.W. Bjerke, E. Malnes, and T.V. Callaghan. 2010. "Snow and Ice" Sami TEK and Science in concert for understanding climate change effects on reindeer pasturing. Polar Record 47: 202-217.

Robinson, R.A., et al. 2009. Travelling through a warming world: climate change and migratory species. Endangered Species Research 7: 87-99.

Saxe, H., G.R. Melvin, M.G.R. Cannell, O. Johnsen, M.G. Ryan, and G. Vourlitis. 2001. Tree and forest functioning in response to global warming. New Phytologist 149: 369-400.

Sharp, M., M. Ananicheva, A. Arendt, J-O Hagen, R. Hock, E. Joseberger, R.D. Moore, W.T. Pfeffer, and G.J. Wolken. 2011. Chapter 7: Mountain glaciers and ice caps. In Snow, Water, Ice and Permafrost in the Arctic (SWIPA). Oslo: Arctic Monitoring and Assessment Programme (AMAP).

Sicart, J.-E., J.W. Pomeroy, R.L.H. Essery, J. Hardy, T. Link, and D. Marks. 2004. A sensitivity study of daytime net radiation during snowmelt to forest canopy and atmospheric conditions. Journal of Hydrometeorology 5: 774-784.

Sitch, S., C. Huntingford, N. Gedney, P.E. Levy, M. Lomas, S.L. Piao, R. Betts, P. Ciais, et al. 2008. Evaluation of the terrestrial carbon cycle, future plant geography and climate-carbon cycle feedbacks using five Dynamic Global Vegetation Models (DGVMs). Global Change Biology 14: 2015-2039.

Snyder, J.M., and B. Stonehouse. 2007. Prospects for polar tourism. Wallingford: Cabi Publishing.

Starr, G., S.F. Oberbauer, and L.E. Ahlquist. 2008. The photosynthetic response of Alaskan tundra plants to increased season length and soil warming. Arctic, Antarctic, and Alpine Research 40: 181-191.

Stewart, E.J. 2007. Sustainable cruise tourism in Arctic Canada: An integrated coastal management approach. Tourism in Marine Environments 3: 77-88.

Stewart, E.J., S.E.L. Howell, D. Draper, J. Yackel, and A. Tivy. 2007. Sea ice in Canada's Arctic: Implications for cruise tourism. Arctic 60: 370-380.

Stirling, I., and T.G. Smith. 2004. Implications of warm temperatures and an unusual rain event for the survival of ringed seals on the coast on southeastern Baffin Island. Arctic 57: 59-67.

Tape, K., M. Sturm, and C. Racine. 2006. The evidence for shrub expansion in Northern Alaska and the Pan-Arctic. Global Change Biology 12: 686-702.

Turunen, M., P. Soppela, H. Kinnunen, M.-L. Sutinen, and F. Martz. 2009. Does climate change influence the availability and quality of reindeer forage plants? Polar Biology 32: 813-832. doi: 10.1007/s00300-009-0609-2.

Walland, D.J., and I. Simmonds. 1997. Modeled atmospheric response to changes in Northern Hemisphere snow cover. Climate Dynamics 13: 25-34.

Walker, D.A., W.D. Billings, and J.G. De Molenaar. 2001. Snowvegetation interactions in tundra environments, pp 266-324. In Snow Ecology: an interdisciplinary examination of snow-covered ecosystems, ed. H.G. Jones, J.W. Pomeroy, D.A. Walker, and R.W. Hoham. Cambridge: Cambridge University Press.

Walsh, J.E., J.E. Overland, P.Y. Groisman, and B. Rudolf. 2011a. Chapter 2: Arctic climate: Recent variations. In Snow, water, ice and permafrost in the Arctic (SWIPA). Oslo: Arctic Monitoring and Assessment Programme (AMAP).

Walsh, J.E., J.E. Overland, P.Y. Groisman, and B. Rudolf. $2011 \mathrm{~b}$. Ongoing climate change in the Arctic. In Arctic cryosphere-
Changes and impacts, ed. T.V. Callaghan, M. Johansson, and T.D. Prowse. Ambio 40(S1). doi:10.1007/s13280-011-0211-z.

Wolf, A., K. Larsson, and T.V. Callaghan. 2008. Future vegetation changes in the Barents Region. Climatic Change 87: $51-73$

Woo, M.K. 1980. Hydrology of a small lake in the Canadian High Arctic. Arctic and Alpine Research 12: 227-235.

Woo, M.K., and X.J. Guan. 2006. Hydrological connectivity and seasonal storage change of tundra ponds in a polar oasis environment, Canadian High Arctic. Permafrost and Periglacial Processes 17: 309-323.

Yarie, J.H. 2008. Effects of moisture limitation on tree growth in upland and floodplain forest ecosystems in interior Alaska. Forest Ecology and Management 256: 1055-1063.

\section{AUTHOR BIOGRAPHIES}

Terry V. Callaghan $(\bowtie)$ is a Distinguished Research Professor at the Royal Swedish Academy of Sciences and Professor of Arctic Ecology at Universities of Sheffield, UK and Lund, Sweden. He specializes in arctic ecology, and climate and UV-B radiation impacts on arctic ecosystems.

Address: Royal Swedish Academy of Sciences, 10405 Stockholm, Sweden.

e-mail: terry_callaghan@btinternet.com

Margareta Johansson is a researcher at the Department of Earth and Ecosystem Sciences, Lund University and at the Royal Swedish Academy of Sciences, Stockholm, Sweden. She specializes in permafrost dynamics in relation to climate change and its impact on ecosystems.

Address: Department of Earth and Ecosystem Sciences, Division of Physical Geography and Ecosystem Analyses, Lund University, Sölvegatan 12, 22362 Lund, Sweden.

e-mail: margareta.johansson@nateko.lu.se

Ross D. Brown is a Research Scientist with the Climate Research Division of Environment Canada located at the Ouranos Climate Consortium in Montreal, Canada. His research interests include documenting and understanding snow cover variability and change, the representation of snow processes in climate and hydrological models and the validation of snow cover in regional and global climate models.

Address: Ouranos, 550 Sherbrooke St. West, 19th Floor, Montréal, QC H3A 1B9, Canada.

e-mail: ross.brown@ec.gc.ca

Pavel Ya. Groisman is a Research Scientist with the Global Climate Applications Division of the National Climatic Data Center/NOAA, Asheville, North Carolina USA. His research interests include climate, data synthesis and analysis, the diagnosis of climate variations, and Arctic climate.

Address: National Climatic Data Center, NOAA, Asheville, NC, USA

e-mail: Pasha.Groisman@noaa.gov

Niklas Labba is the leader of Gáisi Sámi Centre in Tromsø Norway. His research interests include traditional Sámi ecological knowledge and reindeer herding economy.

Address: Gáisi Sámi Centre, Lakselvbukt, 9042 Laksvatn, Norway. e-mail:n.labba@gmail.com

Vladimir Radionov is the Head of the Department of Meteorology at Arctic and Antarctic Research Institute, Saint Petersburg. His research interests include analysis and generalization of hydrometeorological 
and solar radiation data in both polar regions.

Address: AARI, 38 Bering Str., St. Petersburg 199397, Russia.

e-mail: vradion@aari.ru

Raymond S. Bradley is a Distinguished Professor in the Department of Geosciences, and Director of the Climate System Research Center at the University of Massachusetts, Amherst. He specializes in Arctic climate and paleoclimate.

Address: Department of Geosciences, 233 Morrill Science Center, University of Massachusetts, 611 North Pleasant Street, Amherst, MA 01003-9297, USA.

e-mail: rbradley@geo.umass.edu

Sylvie Blangy is a researcher and an associate professor at the Tourism Chair at UQAM. Her research interests are adaptation to climate change for the tourism industry, impact of mining development on Caribou and human health and she is exploring new research methodologies linking local expertise and scientific knowledge, addressing community concerns and priorities.

Address: Université du Québec à Montréal, Case postale 8888, Succursale Centre-ville, Montréal, QC H3C 3P8, Canada.

e-mail: sblangy@gmail.com

Olga N. Bulygina is Lead Scientist at the Department of Climatology at the All-Russian Institute for Hydrometeorological Information, Obninsk, Kaluga Region, The Russian Federation. Her research interests include climatic data quality control, archiving, synthesis, analysis and dissemination for the territory of the Commonwealth of Independent States.

Address: All-Russian Research Institute of Hydrometeorological Information - World Data Centre (RIHMI-WDC), 6 Koroleva Street, Obninsk, Kaluga Region 249035, The Russian Federation.

e-mail: bulygina@meteo.ru

Torben R. Christensen is a Professor at the Department of Earth and Ecosystem Sciences, Lund University, Sweden. He specializes in how vegetation and ecosystem processes respond and provide feedback effects on climate under changing environmental conditions.

Address: Department of Earth and Ecosystem Sciences, Division of Physical Geography and Ecosystem Analyses, Lund University, Sölvegatan 12, 22362 Lund, Sweden.

e-mail: torben.christensen@nateko.lu.se

Jonathan E. Colman is a senior scientist at the Department of Biology, University of Oslo and an Associate Professor at the Norwegian University of Life Sciences, Department of Ecology and Natural Resource Management. His research includes wild and semidomestic reindeer ecology, large herbivore pasture dynamics and wildlife interactions with anthropogenic development.

Address: Department of Biology, UiO, Pb. 1066 Blindern, 0316 Oslo, Norway.

Address: Department of Ecology and Natural Resource Management, UMB, P.O. Box 5003, 1432 Ås, Norway.

e-mail: j.e.colman@bio.uio.no; jonathan.colman@umb.no

Richard L. H. Essery is a Reader in the School of GeoSciences at the University of Edinburgh with research interests in modelling and observation of land-atmosphere interactions in cold regions.

Address: School of Geosciences, University of Edinburgh, Scotland, UK.

e-mail: ressery@staffmail.ed.ac.uk

Bruce C. Forbes is Research Professor in Global Change at the Arctic Centre, University of Lapland. His research interests encompass land use and climate change in arctic ecosystems. He works closely with indigenous reindeer herders (Nenets, Sámi) and specializes in understanding anthropogenic disturbance regimes, reindeer rangeland dynamics, shrub tundra responses to warming, and resilience in linked social-ecological systems.

Address: P.O. Box 122, 96101 Rovaniemi, Finland.

e-mail: bforbes@ulapland.fi

Mads C. Forchhammer is a Professor and Head of Ecosystem Ecology at Department of Bioscience, Aarhus University. He has a comprehensive statistical and theoretical background in population ecology. Recent work focuses on advanced multivariate and nonlinear analyses of climate-ecology interactions in time and space, including species ecology, population dynamics and ecosystem functioning.

Address: Department of Bioscience, Aarhus University, Denmark and Greenland Climate Research Center, Nuuk, Greenland.

e-mail: mcf@dmu.dk

Vladimir N. Golubev is Lead Scientist at the Laboratory of Snow Avalanches and Mudflows at Geographical Faculty of Moscow State University, Moscow, the Russian Federation. His research interests include ice crystal formation in atmosphere, solid precipitation and snowfalls, modelling of vapour transfer and isotopic content of snow cover.

Address: Laboratory of Snow Avalanches and Mudflows, Faculty of Geography, Moscow State University, Leninskie Gory, 1, 119991 Moscow, The Russian Federation.

e-mail: golubev@geol.msu.ru

Richard E. Honrath (Deceased) was a Professor at Michigan Technological University at the Department of Geological and Mining Engineering and Sciences and Department of Civil and Environmental Engineering.

Address: Departments of Geological and Mining Engineering and Sciences, and Civil and Environmental Engineering, Michigan Technological University, Houghton, USA.

Glenn P. Juday is Professor of Forest Ecology in the School of Natural Resources and Agricultural Sciences of the University of Alaska Fairbanks. His research interests include: climate sensitivity of boreal forest growth and forest health, structure and biodiversity of older forest communities, and forest development following disturbance.

Address: School of Natural Resources and Agricultural Sciences, P.O. Box 757200, Fairbanks, AK 99775-7200, USA.

e-mail: gjuday@alsaska.edu

\section{Anna V. Meshcherskaya}

Address: 7 Karbysheva Street, St. Petersburg 194021, Russia. e-mail: meschers@main.mgo.rssi.ru

Gareth K. Phoenix is a Senior Lecturer at the Department of Animal and Plant Sciences, University of Sheffield, UK. His research interests include the impacts of global change on vegetation and ecosystem process (in particular carbon and nutrient cycling), and how these ecosystem processes are impacted by plant community structure.

Address: Department of Animal and Plant Sciences, University of Sheffield, Western Bank, Sheffield S10 2TN, UK.

e-mail: g.phoenix@ sheffield.ac.uk

John Pomeroy is the Canada Research Chair in Water Resources and Climate Change and Director of the Centre for Hydrology at the University of Saskatchewan, Saskatoon, Canada with a research base, the Coldwater Centre, on the campus of the Biogeoscience Institute in Canadian Rocky Mountains. His research interests include snow accumulation, redistribution and melt processes with relevance to cold regions hydrological modelling, climate and ecohydrology. 
Address: Centre for Hydrology, University of Saskatchewan, 117 Science Place, Saskatoon, SASK S7N 5C8, Canada. e-mail: john.pomeroy@usask.ca

Arja Rautio is research professor in Centre for Arctic Medicine at Thule Institute in University of Oulu, Finland, with research interests in human health and well-being in circumpolar area.

Address: Centre for Arctic Medicine, Thule Institute, University of Oulu, P.O. Box 7300, 90014 Oulu, Finland.

e-mail: arja.rautio@oulu.fi

David A. Robinson is a Professor at the Department of Geography at Rutgers, The State University of New Jersey. His research interests include regional to global snow cover kinematics and dynamics, interactions of snow cover with other climate elements, and the collection and archiving of accurate climatic data.

Address: Department of Geography, Rutgers University, 54 Joyce Kilmer Avenue, Piscataway 08854, NJ, USA.

e-mail: david.robinson@ rutgers.edu

Niels M. Schmidt is a senior researcher at the Department of Bioscience, Aarhus University, Denmark. He is in charge of the biological monitoring at Zackenberg, and his research interests include environmental impacts on the population dynamics of arctic organisms.

Address: Department of Bioscience, Aarhus University, Frederiksborgvej 399, 4000 Roskilde, Denmark.

e-mail: nms@dmu.dk

Mark C. Serreze is Director of the National Snow and Ice Data Center and Professor of Geography at the University of Colorado Boulder. His Arctic research interests include atmosphere-sea ice interactions, synoptic climatology, boundary layer problems, numerical weather prediction and climate change. Efforts over the past 10 years have increasingly focused on trying to make sense of the rapid environmental changes being observed in the Arctic.

Address: CIRES/NSIDC, University of Colorado, Campus Box 449, Boulder, CO 80309-0449, USA.

e-mail: serreze@nsidc.org

Vladimir P. Shevchenko is a Leading Scientist at the Geological Department of P.P. Shirshov Institute of Oceanology, Russian Academy of Sciences, Moscow, Russia. His research interests include studies of processes of modern marine sedimentation (aerosols, snow, ice, suspended matter), especially in the Arctic.

Address: P.P. Shirshov Institute of Oceanology RAS, 36 Nakhimovsky Prospect, 117997 Moscow, Russia.

e-mail: vshevch@ocean.ru

Alexander I. Shiklomanov is a Research Scientist at the University of New Hampshire. His research is focusing on cold regions runoff formation and discharge of surface waters to the Arctic seas.
Address: Institute for the Study of Earth, Oceans and Space, University of New Hampshire, Durham, NH 03824-3525, USA.

e-mail: Alex.Shiklomanov@unh.edu

Andrey B. Shmakin is the head of Laboratory of Climatology at the Institute of Geography, Russian Academy of Sciences. His research interests include diagnosis of contemporary changes of climate and snow cover characteristics, numerical modelling of the soil-vegetation-snow-atmosphere heat/water transfer, and applied climatic research.

Address: Institute of Geography, 29 Staromonetny St, Moscow 119017, Russia.

e-mail: ashmakin@igras.ru

Peter Sköld is a Professor of History, Sami Culture and Society Development and executive director of the Northern Studies Centre of Excellence at Umeå University. He specializes in historical demography, health and vulnerability among indigenous peoples.

Address: Centre for Sami Research, Umeå University, SE-901 87 Umeå, Sweden.

e-mail: peter.skold@cesam.umu.se

Matthew Sturm is a Research Scientist at the Cold Regions Research and Engineering Laboratory (CRREL). His research is focusing on thermal effects of snow cover, snow cover's effect on the environment particularly in polar and sub-polar areas, and snow and vegetation.

Address: USA-CRREL-Alaska, P.O. Box 35170, Ft. Wainwright, AK 99703-0170, USA.

e-mail: Matthew.Sturm@usace.army.mil

Ming-ko Woo is Professor Emeritus at the McMaster University, Canada. His specialization is in snow, permafrost, wetlands and water-related research.

Address: School of Geography \& Earth Sciences, Building 206 McMaster University 1280 Main Street, West Hamilton, ON L8S 4K1, Canada.

e-mail:woo@mcmaster.ca

Eric F. Wood is the Susan Dod Brown Professor of Civil and Environmental Engineering at Princeton University. His research interests include global scale modelling and remote sensing of the terrestrial water and energy cycles. Over the Arctic domain, he and his group have studied the hydrologic trends and impacts from climate change over the last 50 years.

Address: Department of Civil and Environmental Engineering, Princeton University, Princeton, NJ 08544, USA.

e-mail: efwood@princeton.edu 